\title{
The Review of Technology Industry Policy about New Energy Vehicle in China since the New Century
}

\author{
Yimiao Huang ${ }^{1, ~ a ~}$, Yanyu Chen ${ }^{1,2, b}$ \\ 1Zhejiang Traffic Technician College, Jinhua 321015, China; \\ ${ }^{2}$ School of Management, Northwestern Polytechnical University, Xi'an 710072, China. \\ a346362960@qq.com, bxianggood666@sina.com
}

Keywords: New energy vehicle, Industrial policy, Review.

\begin{abstract}
From the point of view of 2001-2015 new energy automobile industry policy in china, the author reviews the new energy automobile industry policy in the three five-year plan period, and the three periods were defined as the science and technology strategy stage, industry strategic stage and national strategic stage. Based on the above analysis, the author analyzes Characteristics of the development of new energy automobile industry.
\end{abstract}

\section{Introduction}

Automobile as a product of modern industrial civilization, for the development of human social economy has made important contributions. But with the economic and social development, people pay more and more attention to environmental protection, and automobile exhaust emissions as the main cause of haze, people are increasingly concerned about the role of new energy vehicles alternative. Compared with the traditional fuel vehicles, new energy vehicles can not only effectively reduce emissions, according to the calculation of new energy vehicles exhaust emissions than fuel vehicles to reduce more than Jiucheng; but also boost the economic and social sustainable development, an effective solution to energy Consumption. Therefore, this paper focuses on combing and analyzing the policies of China's new energy automobile industry in the past 15 years, with a view to making constructive suggestions on the development of China's new energy automobile industry.

\section{Analysis on the Policy of New Energy Automobile Industry in China}

China's new energy vehicle development began in 1990s, when there is no concept of industrial policy. In the fifteenth plan period, the state has developed a new energy vehicle technology plan, and "863" projects and other national projects, has invested more than 20 billion yuan R\&D funding, focusing on research and development New energy vehicles and related parts, to explore the feasibility of various technical routes, since then for the development of China's new energy automotive industry has laid a solid foundation. With the economic and social development, the state pays more and more attention to the development of new energy automotive industry. Especially in 2009 to 2016 nearly eight years' time, China's new energy automotive industry with the continuous evolution of national policy. 2015, Premier Li Keqiang in the "Government Work Report" clearly in the new energy vehicles as the direction of the development of the automotive industry as a strategic emerging industries, the new energy automotive industry to a higher level. Figure 1 shows the distribution of policies related to new energy vehicles in China from 2001 to 2016. 


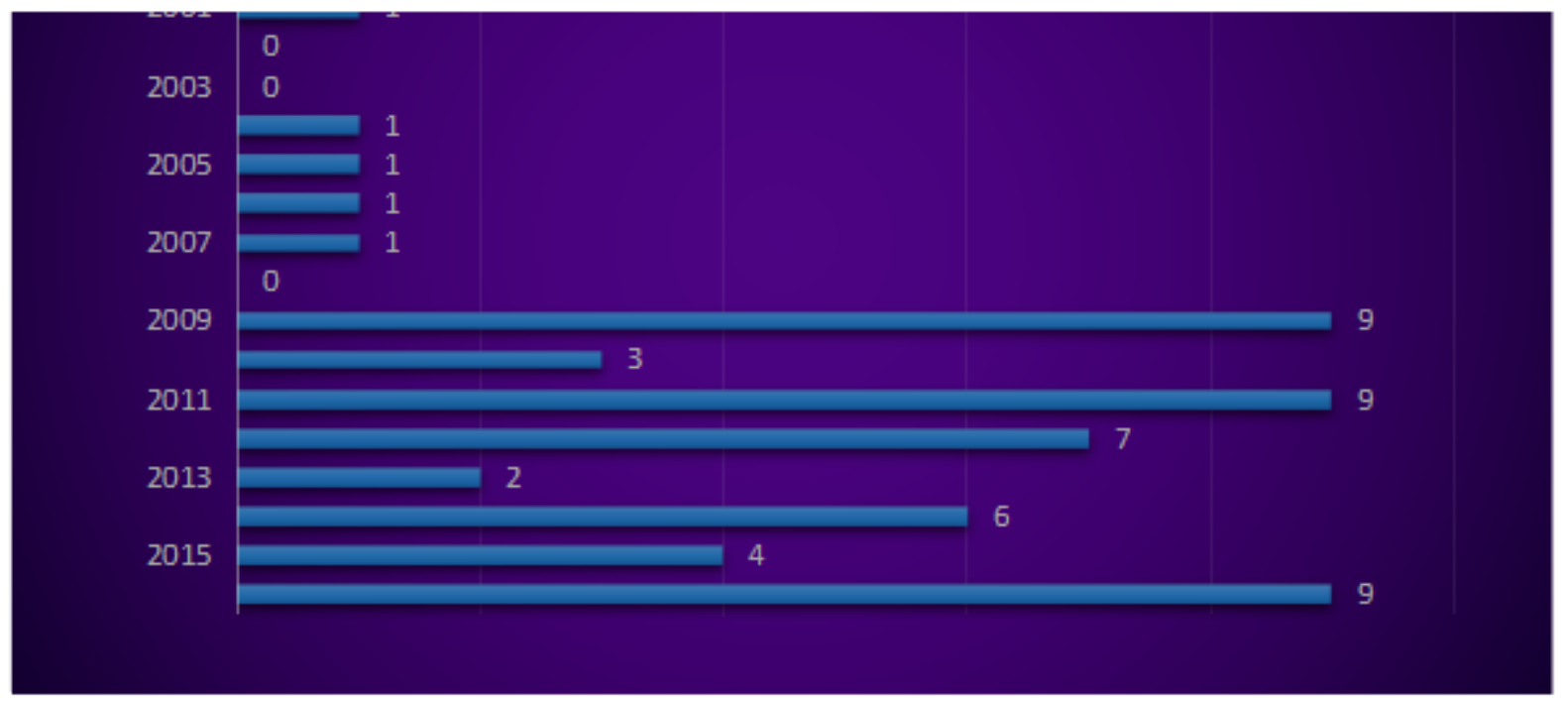

Figure 12001 - 2016 China introduced the new energy vehicle industry related to the number of policies

From Figure 1, we can understand that China's new energy vehicles for the relevant policies since 2001 increased year by year, and after 2009, explosive growth. From the time point of view, in 2009 at the end of the "Eleventh Five-Year plan", you can know that it is during the second five, China's new energy automotive industry has been the government's attention, ushered in an unprecedented scale of policy support.

\section{1 "Tenth Five-Year Plan" (2001 2005) Period -- Strategic Stage of Science and Technology}

At the beginning of the new century, Europe and the United States and other developed countries, all the new energy vehicles as a strategic high point to consider, have put power to strengthen the development of the industry. China as a developing country, in the traditional automotive and developed countries compared to the gap is very large, and in the new energy vehicles, we and Europe and the United States and Japan have the same opportunity to Energy vehicles and Western developed countries in the field of a higher. China in the "Tenth Five-Year plan" period developed a new energy vehicle technology plan, and in 2001 named the "863" plan. The direct investment of nearly 900 million yuan of funds, engaged in research and development of new energy vehicles. But at that time the relevant parts of the country to take into account China's new energy vehicle research and development has just started, there is no advantage in the key technology, can not rush to determine the direction of development. Therefore, the choice of technical routes, the use of a multi-pronged electric vehicle "three vertical and three horizontal" matrix R\&D layout, a variety of feasible technologies have to be some support. At the same time, in order to explore the commercialization of electric vehicles operating mode, in the "Eleventh Five-Year plan" period, the Ministry of Science and Technology has Beijing and other six cities identified as electric vehicle demonstration city. Table 1 for "Eleventh Five-Year plan plan" during the introduction of China's major new energy automotive industry policy. 
Table 1. China's major policy of new energy vehicles during the "tenth Five-Year plan" period

\begin{tabular}{|c|c|c|c|c|c|}
\hline Time & Policy name & $\begin{array}{c}\text { Promulgated } \\
\text { by }\end{array}$ & Main content & Aim & Significance \\
\hline 2001 & $\begin{array}{l}\text { "863 plan" about } \\
\text { electric vehicle } \\
\text { major projects }\end{array}$ & $\begin{array}{c}\text { National Science } \\
\text { and Technology } \\
\text { Education } \\
\text { Leading Group }\end{array}$ & $\begin{array}{l}\text { The formation of three technical routes, } \\
\text { including pure electric, hybrid electric and } \\
\text { fuel-based, the formation of three common } \\
\text { technologies, including power battery, drive } \\
\text { motor, powertrain control system }\end{array}$ & $\begin{array}{l}\text { Narrow the gap with } \\
\text { developed countries in the } \\
\text { field of new energy } \\
\text { vehicles }\end{array}$ & $\begin{array}{l}\text { China's first } \\
\text { policy on new } \\
\text { energy } \\
\text { automotive } \\
\text { industry }\end{array}$ \\
\hline 2004 & $\begin{array}{l}\text { Automobile } \\
\text { industry } \\
\text { development } \\
\text { policy }\end{array}$ & $\begin{array}{l}\text { National } \\
\text { Development } \\
\text { and Reform } \\
\text { Commission }\end{array}$ & $\begin{array}{l}\text { Focus on the development of energy-saving } \\
\text { environmental protection, sustainable } \\
\text { development of Automotive Technology }\end{array}$ & $\begin{array}{l}\text { Guide the Chinese } \\
\text { automobile industry to } \\
\text { embark on a sustained and } \\
\text { healthy development path }\end{array}$ & $\begin{array}{l}\text { Began to } \\
\text { develop new } \\
\text { energy vehicles } \\
\text { as part of the } \\
\text { development of } \\
\text { the automotive } \\
\text { industry }\end{array}$ \\
\hline 2005 & $\begin{array}{c}\text { A series of } \\
\text { policies }\end{array}$ & $\begin{array}{l}\text { Ministry of } \\
\text { Finance, et al }\end{array}$ & $\begin{array}{c}\text { Determine the Beijing, Wuhan, Tianjin, } \\
\text { Zhuzhou, Weihai, Hangzhou, six cities for the } \\
\text { demonstration of electric vehicles operating } \\
\text { city }\end{array}$ & $\begin{array}{l}\text { Increase the share of } \\
\text { electric car ownership in } \\
\text { car ownership }\end{array}$ & $\begin{array}{l}\text { Promote the } \\
\text { development of } \\
\text { clean vehicles, } \\
\text { electric vehicles } \\
\text { and policy } \\
\text { measures }\end{array}$ \\
\hline
\end{tabular}

\section{2 "Eleventh Five - Year Plan" (2006 2010) Period -- Industrial Strategy Stage}

The "Eleventh Five-Year plan" period, is the development of new energy vehicles in China a peak period, during which a number of related policies. In particular, the second half of the "Eleventh Five-Year plan", that is, in 2008, the international oil prices because the global economic crisis from 80 US dollars / barrel rose to 147 US dollars / barrel, high oil prices make car consumers have to rethink the traditional fuel vehicles cost. In this case, the new energy vehicles show its energy saving and environmental protection to save money advantage. Automobile manufacturers to see the broad prospects of the new energy automotive industry, increased $R \& D$ and production efforts, the Government from the economic and social sustainable scientific development point of view, the introduction of policies to vigorously promote the development of new energy vehicles, new energy automotive industry development Entered the stage of industrial strategy development.

"Eleventh Five-Year plan" was a "tenth Five-Year plan" follow-up. With the government's development during the "Eleventh Five-Year plan" period, China's new energy vehicles have basically have the basis of industrialization, pure electric vehicles and plug-in hybrid cars have begun small-scale market , Introduced a series of substantive related industrial policy. For example, in 2006 the Ministry of Finance for the hybrid cars and other energy-saving, environmentally friendly characteristics of the implementation of tax incentives; since 2007 the state invested nearly 20 billion yuan for the "863 Plan" electric vehicle major projects, and with the same year on November 1 From the implementation of new energy vehicles containing the production enterprise qualification, production access conditions and reporting requirements, including the "new energy vehicle production access management rules", the industry believes that the country really encourages the development of new energy vehicles, to promote marketization The development of new energy vehicles in 2009 is unprecedented, not only in the year the State Council promulgated the "auto industry restructuring and revitalization plan" for the first time put forward a new energy vehicle strategy, but also arranged 10 billion yuan to support the new Energy vehicles and key parts of the industrialization. It can be said that in 2009 the new energy vehicles is a milestone in the meaning of the year! "Eleventh Five-Year plan" period of China's new energy automotive industry policy see Table 2. 
Table 2. China's new energy automotive industry policy during "Eleventh Five-Year plan" period

\begin{tabular}{|c|c|c|c|c|c|}
\hline Time & Policy name & $\begin{array}{c}\text { Promulgated } \\
\text { by }\end{array}$ & Main content & Aim & Significance \\
\hline 2006.4 & New consumption tax policy & $\begin{array}{l}\text { Ministry of } \\
\text { Finance }\end{array}$ & $\begin{array}{c}\text { Tax incentives for } \\
\text { energy-saving, } \\
\text { environmental protection } \\
\text { and other characteristics } \\
\text { of the hybrid vehicle }\end{array}$ & $\begin{array}{l}\text { Use tax relief to } \\
\text { support the } \\
\text { development of } \\
\text { new energy } \\
\text { vehicles }\end{array}$ & $\begin{array}{l}\text { Encourage more } \\
\text { enterprises to } \\
\text { develop new } \\
\text { energy vehicles }\end{array}$ \\
\hline 2007.11 & $\begin{array}{l}\text { Production access rules on new energy } \\
\text { vehicles }\end{array}$ & $\begin{array}{l}\text { Ministry of } \\
\text { Industry and } \\
\text { Information } \\
\text { Technology }\end{array}$ & $\begin{array}{l}\text { Clearly defined the new } \\
\text { energy vehicles, } \\
\text { production access } \\
\text { conditions and reporting } \\
\text { requirements and so on }\end{array}$ & $\begin{array}{l}\text { Identify industry } \\
\text { guidelines for } \\
\text { new energy } \\
\text { vehicles }\end{array}$ & $\begin{array}{c}\text { The state began to } \\
\text { really encourage } \\
\text { the development } \\
\text { of new energy } \\
\text { vehicles }\end{array}$ \\
\hline 2007.12 & $\begin{array}{l}\text { Guidance on industrial structure adjustment } \\
\text { (2007) }\end{array}$ & $\begin{array}{l}\text { Development } \\
\text { and Reform } \\
\text { Commission }\end{array}$ & $\begin{array}{l}\text { Make"new energy } \\
\text { vehicles" increase into } \\
\text { the encouraged industry } \\
\text { directory }\end{array}$ & $\begin{array}{l}\text { Support the } \\
\text { development of } \\
\text { new energy } \\
\text { vehicles }\end{array}$ & $\begin{array}{l}\text { Pointing out the } \\
\text { development } \\
\text { direction of the } \\
\text { automobile } \\
\text { industry in the } \\
\text { new period }\end{array}$ \\
\hline 2009.1 & $\begin{array}{l}\text { Notice on Carrying out Pilot Project of } \\
\text { Demonstration and Popularization of Energy } \\
\text { Saving and New Energy Vehicles }\end{array}$ & $\begin{array}{l}\text { Ministry of } \\
\text { Science and } \\
\text { Technology, } \\
\text { et al }\end{array}$ & $\begin{array}{c}\text { Carry out energy-saving } \\
\text { and new energy vehicle } \\
\text { demonstration pilot work } \\
\text { in Beijing and other } 13 \\
\text { cities }\end{array}$ & $\begin{array}{l}\text { Expect from the } \\
\text { field of public } \\
\text { services cut into } \\
\text { the rapid opening } \\
\text { of new energy } \\
\text { vehicles }\end{array}$ & $\begin{array}{l}\text { Has a certain } \\
\text { effect }\end{array}$ \\
\hline 2009.2 & $\begin{array}{l}\text { "Ten-City-Thousand-Vehicle"--Demonstratio } \\
\text { n project of electric vehicle }\end{array}$ & $\begin{array}{l}\text { Ministry of } \\
\text { Finance,et al }\end{array}$ & $\begin{array}{c}\text { Decide to launch } 1000 \\
\text { new energy vehicles in } \\
\text { the public sector of the } \\
\text { city in the past } 3 \text { years at } \\
\text { a rate of about } 10 \text { cities a } \\
\text { year }\end{array}$ & $\begin{array}{l}\text { Speed up the use } \\
\text { of new energy } \\
\text { vehicles in the } \\
\text { public domain }\end{array}$ & $\begin{array}{l}\text { China 's new } \\
\text { energy vehicles } \\
\text { really began to } \\
\text { industrialization }\end{array}$ \\
\hline 2009.3 & $\begin{array}{l}\text { Restructuring and revitalization plan of } \\
\text { Automotive industry }\end{array}$ & $\begin{array}{l}\text { Office of the } \\
\text { State Council }\end{array}$ & $\begin{array}{c}\text { Promote the new energy } \\
\text { vehicle strategy, and form } \\
\text { the scale of production } \\
\text { and operation of electric } \\
\text { vehicles }\end{array}$ & $\begin{array}{l}\text { Promote the } \\
\text { industrialization } \\
\text { of energy-saving } \\
\text { and new energy } \\
\text { vehicles further }\end{array}$ & $\begin{array}{l}\text { The state had } \\
\text { made } \\
\text { unprecedented } \\
\text { plans for new } \\
\text { energy vehicles }\end{array}$ \\
\hline 2009.6 & $\begin{array}{l}\text { New energy automobile production enterprises } \\
\text { and product access management rules }\end{array}$ & $\begin{array}{l}\text { Ministry of } \\
\text { Industry and } \\
\text { Information } \\
\text { Technology }\end{array}$ & $\begin{array}{l}\text { Clear the new energy } \\
\text { automotive companies } \\
\text { and products access } \\
\text { conditions }\end{array}$ & $\begin{array}{l}\text { Set the threshold } \\
\text { for enterprise to } \\
\text { enter the new } \\
\text { energy } \\
\text { automotive } \\
\text { industry }\end{array}$ & $\begin{array}{l}\text { To prevent the } \\
\text { structural } \\
\text { problems of } \\
\text { overcapacity }\end{array}$ \\
\hline 2010.5 & $\begin{array}{c}\text { Notice on Expanding the Work of } \\
\text { Demonstration and Popularization of Energy } \\
\text { Saving and New Energy Vehicles in Public } \\
\text { Service }\end{array}$ & $\begin{array}{l}\text { Ministry of } \\
\text { Science and } \\
\text { Technology, } \\
\text { et al }\end{array}$ & $\begin{array}{l}\text { promote } 13 \text { pilot cities to } \\
\text { expand to } 20 \text {, and further } \\
\text { expanded to } 25 \text { cities }\end{array}$ & $\begin{array}{l}\text { Expand the field } \\
\text { of new energy } \\
\text { vehicles to } \\
\text { promote }\end{array}$ & $\begin{array}{l}\text { Marking the } \\
\text { development of } \\
\text { China's new } \\
\text { energy vehicles } \\
\text { into the } \\
\text { substantive policy } \\
\text { support stage }\end{array}$ \\
\hline 2010.6 & $\begin{array}{l}\text { Interim Measures for the Administration of } \\
\text { Private Purchase of New Energy Vehicles }\end{array}$ & $\begin{array}{l}\text { Ministry of } \\
\text { Finance }\end{array}$ & $\begin{array}{l}\text { Try to carry out private } \\
\text { purchase of new energy } \\
\text { vehicles to give subsidies }\end{array}$ & $\begin{array}{l}\text { Encourage } \\
\text { private to buy } \\
\text { new energy } \\
\text { vehicles }\end{array}$ & $\begin{array}{l}\text { Give subsidies to } \\
\text { private purchase } \\
\text { for buying new } \\
\text { energy vehicles }\end{array}$ \\
\hline 2010. & $\begin{array}{l}\text { Decision on Accelerating the Cultivation and } \\
\text { Development of Strategic Emerging Industries }\end{array}$ & $\begin{array}{l}\text { Office of the } \\
\text { State Council }\end{array}$ & $\begin{array}{l}\text { Increase new energy } \\
\text { vehicles into the strategic } \\
\text { emerging industries }\end{array}$ & $\begin{array}{l}\text { To seize the } \\
\text { strategic high } \\
\text { ground of } \\
\text { international } \\
\text { competition }\end{array}$ & $\begin{array}{c}\text { The development } \\
\text { of new energy } \\
\text { industry officially } \\
\text { rose to the } \\
\text { national strategic } \\
\text { level }\end{array}$ \\
\hline
\end{tabular}

2.3 "Twelfth Five - Year Plan" (2006 2010) Period -- National Strategic Stage

"Twelfth Five Year plan" period is China's new energy automotive industry, which is an important strategic opportunity for the development. March 2011 national announcement of the "second Five-Year plan Plan" made it clear that the new energy vehicles as one of the strategic emerging 
industries, will focus on the development of fuel cell vehicle technology, pure electric vehicles, plug-in hybrid vehicles, and promote Its large-scale commercial demonstration projects, thus forming industrial applications. This marks the development of new energy vehicles from the industrial strategy to a high level of national strategic level, the new situation to vigorously promote the rapid development of new energy automotive industry, play a very important plan guidance.

In the same year, China's automotive industry also introduced the corresponding "second - five year" plan, the new energy vehicles as the focus of the development of the next five years to treat. The focus of the development of new energy vehicles is focused on the automotive electric and power hybrid two major technical aspects, and independent brands will be supported. At the same time, and strive to 2015, the domestic sales of new energy vehicles reached the goal of millions, so that China has become the world's largest producer of new energy vehicles. The whole "second five" during the government to further increase the financial support, subsidies unprecedented. Under the stimulus policy, since the second half of 2014, the domestic new energy vehicle market showed explosive growth. The first nine months of 2015 new energy vehicle production reached 156,200, an increase of nearly 3 times, for the 2014 year 2 times. During"Twelfth Five Year plan" period the introduction of new energy automotive industry policy in Table 3.

Table 3. The introduction of new energy automotive industry policy during "Twelfth Five Year plan" period

\begin{tabular}{|c|c|c|c|c|c|}
\hline Time & Policy name & Promulgated by & Main content & Aim & Significance \\
\hline 2011.2 & $\begin{array}{l}\text { People 's Republic of } \\
\text { China "Vehicle and } \\
\text { Vessel Tax Law" }\end{array}$ & $\begin{array}{l}\text { National People's } \\
\text { Congress }\end{array}$ & $\begin{array}{l}\text { The new"Vehicle and Vessel Tax } \\
\text { Law" provides that "the use of new } \\
\text { energy vehicles can be reduced or } \\
\text { exempted from travel tax" }\end{array}$ & $\begin{array}{l}\text { Provide financial support for } \\
\text { the promotion and use of } \\
\text { new energy vehicles }\end{array}$ & $\begin{array}{l}\text { Further promote the } \\
\text { development of new energy } \\
\text { automotive industry }\end{array}$ \\
\hline 2011.3 & $\begin{array}{l}\text { National "Twelfth } \\
\text { Five - Year Plan" }\end{array}$ & $\begin{array}{l}\text { National People's } \\
\text { Congress }\end{array}$ & $\begin{array}{l}\text { New energy vehicles as one of the } \\
\text { strategic emerging industries, will } \\
\text { focus on the development of fuel cell } \\
\text { vehicle technology }\end{array}$ & $\begin{array}{l}\text { Promote the } \\
\text { industrialization of new } \\
\text { energy vehicles }\end{array}$ & $\begin{array}{l}\text { Further promote the } \\
\text { development of new energy } \\
\text { automotive industry }\end{array}$ \\
\hline 2011.7 & $\begin{array}{l}\text { National "Twelfth } \\
\text { Five - Year" science } \\
\text { and technology } \\
\text { development plan }\end{array}$ & $\begin{array}{l}\text { Ministry of science } \\
\text { and technology }\end{array}$ & $\begin{array}{l}\text { Continue to adhere to the "pure } \\
\text { electric drive" strategic objectives } \\
\text { remain unchanged }\end{array}$ & $\begin{array}{l}\text { To achieve the } \\
\text { industrialization of new } \\
\text { energy vehicles }\end{array}$ & $\begin{array}{l}\text { Make R \& D layout } \\
\text { unchanged }\end{array}$ \\
\hline 2011.8 & $\begin{array}{c}\text { A Letter on } \\
\text { Strengthening the } \\
\text { Work of Promoting } \\
\text { Safety Management of } \\
\text { Energy Saving and } \\
\text { New Energy Vehicles }\end{array}$ & $\begin{array}{l}\text { Ministry of Finance, } \\
\text { et al }\end{array}$ & $\begin{array}{l}\text { The pilot cities are required to fully } \\
\text { understand the importance of energy } \\
\text { saving and new energy vehicles } \\
\text { demonstration and promotion of } \\
\text { safety management }\end{array}$ & $\begin{array}{l}\text { Effectively protect the } \\
\text { energy efficiency and } \\
\text { demonstration of the safety } \\
\text { of new energy vehicles }\end{array}$ & $\begin{array}{l}\text { Security issues related to } \\
\text { energy saving and the } \\
\text { development of new energy } \\
\text { vehicles }\end{array}$ \\
\hline 2011.9 & $\begin{array}{l}\text { Notice on Adjusting } \\
\text { the Policy of } \\
\text { Promotion of Energy - } \\
\text { saving Automobile } \\
\text { Promotion }\end{array}$ & $\begin{array}{l}\text { Ministry of Industry } \\
\text { and Information } \\
\text { Technology, et al }\end{array}$ & $\begin{array}{l}\text { Raise the threshold of promotion } \\
\text { subsidies }\end{array}$ & $\begin{array}{l}\text { Promote the improvement of } \\
\text { automotive energy-saving } \\
\text { technology and product } \\
\text { structure optimization and } \\
\text { upgrading }\end{array}$ & $\begin{array}{l}\text { Promote the automobile } \\
\text { production enterprises to } \\
\text { increase energy-saving } \\
\text { technology R \& D investment }\end{array}$ \\
\hline 2011.9 & $\begin{array}{l}\text { Guiding Opinions on } \\
\text { Promoting the } \\
\text { Internationalization of } \\
\text { Strategic Emerging } \\
\text { Industries }\end{array}$ & $\begin{array}{l}\text { Ministry of } \\
\text { Commerce, et al }\end{array}$ & $\begin{array}{l}\text { Cultivate new energy vehicles } \\
\text { multinational companies }\end{array}$ & $\begin{array}{l}\text { Enhance the international } \\
\text { competitiveness of new } \\
\text { energy vehicles }\end{array}$ & $\begin{array}{l}\text { Shorten the gap with } \\
\text { developed countries }\end{array}$ \\
\hline 2011.11 & $\begin{array}{l}\text { Notice on further } \\
\text { doing well the pilot } \\
\text { work of energy saving } \\
\text { and new energy } \\
\text { vehicle demonstration } \\
\text { and popularization }\end{array}$ & $\begin{array}{l}\text { Ministry of Industry } \\
\text { and Information } \\
\text { Technology, et al }\end{array}$ & $\begin{array}{l}\text { Promote the all-round consumption } \\
\text { of new energy vehicles }\end{array}$ & $\begin{array}{l}\text { Create a new energy vehicle } \\
\text { consumption environment } \\
\text { and accelerate the } \\
\text { improvement of product } \\
\text { quality }\end{array}$ & $\begin{array}{l}\text { Highlighting the country's } \\
\text { commitment to the promotion } \\
\text { of new energy vehicles }\end{array}$ \\
\hline 2012.4 & $\begin{array}{l}\text { Energy saving and } \\
\text { new energy } \\
\text { automotive industry } \\
\text { development plan } \\
\text { (2012-2020) }\end{array}$ & The State Council & $\begin{array}{l}\text { Actively promote the construction of } \\
\text { charging facilities, strengthen the } \\
\text { power battery cascade utilization and } \\
\text { recycling management }\end{array}$ & $\begin{array}{l}\text { Promote industrialization, } \\
\text { enhance the supporting } \\
\text { capacity, improve the } \\
\text { management system }\end{array}$ & $\begin{array}{l}\text { Help to enhance the overall } \\
\text { level of China's auto industry }\end{array}$ \\
\hline
\end{tabular}




\section{The Characteristics of China's New Energy Vehicle Industry Development Policy since the New Century}

With summarizing the policy of China 's new energy automobile industry in 2001 - 2015, I found that China's new energy automotive industry has the following characteristics, through the analysis of characteristics to find the direction of development, for better and faster development of new energy automotive industry has a reality significance.

\subsection{Supporting For Industrial R\&D Strongly}

The initial government science and technology projects and enterprise product development originated in the "Tenth Five-Year plan" period. In 2001 the state through the "863 plan" electric vehicle major project ", invested 880 million for the" three vertical and three horizontal "technology research and development investment, and thus led to local and business nearly 2.4 billion R \& D investment. At that time the $\mathrm{R} \& \mathrm{D}$ investment is in the vehicle factory parts enterprises, as well as university research institutions under the joint efforts to product as the goal to do collaborative innovation. To the "Eleventh Five-Year plan" period, the state through the "863 plan" to continue to invest 1.1 billion yuan, focusing on alternative pure electric power systems, hybrid, fuel, fuel cells and other development of a new generation of energy-saving and new energy automotive technology, One five "period, to achieve the scale of alternative fuel vehicles, hybrid cars and pure electric vehicle industry. At that time in the country 1.1 billion R \& D funds, driven by the entire social investment is expected to billions. "Twelfth Five - Year plan" is from 2010 to the end of 2013, through the science and technology plan for the new energy vehicle R \& D spending more than 1.3 billion, the same year the Ministry of Industry and the Ministry of Finance and jointly allocated more than 40 billion yuan of funds to support enterprises, including the development of battery development, New energy vehicle design, including special projects. Up to now, the rough statistics of the country for new energy vehicles R \& D innovation funds have more than 10 billion, I believe the country for new energy vehicles R \& D support will only grow.

\subsection{Focusing On Market Cultivation Very Much}

On the basis of the stage which is in the "Tenth Five-Year plan" strategy of science and technology, the Ministry of Finance, Ministry of Science and Technology to establish a "financial - science and technology linkage" new mechanism, in order to "863 plan" electric vehicle major scientific and technological projects to better transform the results into practical use. At the same time they established a "financial - science and technology linkage" new mechanism for enterprises to give exemplary subsidies. With the Development and Reform Commission and the Ministry of Industry and Information Technology, they promoted the implementation of "Ten-City-Thousand-Vehicle" energy-saving and new energy vehicle demonstration project, in-depth promotion of electric vehicle scientific and technological achievements. Since then, the development of China's new energy automotive industry officially from the scientific research into the important period of promoting industrialization. With scientific and technological research in "Tenth Five-Year plan", "eleventh Five-Year plan", in the 2008 Beijing Olympic Games, the 2010 Shanghai World Expo, "Ten-City-Thousand-Vehicle" demonstration project led the role of China's new energy vehicles from scratch, technology continues to progress , And gradually established with independent intellectual property rights of the new energy vehicle industry chain system. According to relevant information, by the end of 2012, that is, "Ten-City-Thousand-Vehicle" demonstration and promotion of the last year, the country a total of 25 cities to join the "Ten City 1000" promotion project, more than 58 enterprises 210 models into the " Energy-saving and new energy vehicle demonstration and application of recommended models recommended model ", around the demonstration of various types of electric vehicles running more than 27,400, demonstration run more than 250 million kilometers, the cumulative passenger capacity of more than 9.6 billion people.

\subsection{Paying Attention To Standardized Management For Long-Term}

Standardization for the promotion of new energy vehicles as a whole industry healthy development, standardize the order of industrial development is essential. As early as October 2007, the National Development and Reform Commission on the first announcement issued a "new energy 
vehicle production access management rules", which is the new energy automotive industry, the first industry guidelines. After the establishment of the Ministry of Industry, in accordance with the "automobile industry development policy" the relevant provisions and product classification management principles, in June 2009 issued a "new energy vehicle production enterprises and product access management rules", since July 1, 2009, has been implemented for seven years. In 2016, the Ministry of Industry and the Ministry of Industry to amend the "rules", which should be the Ministry of Industry on the existing "rules" of the first revision. Which also fully reflects the development of new energy vehicles into a new stage. At present the new version of "new energy automobile production enterprises and product access regulations" was released in January 2017, July 1, 2017 formally implemented. The new regulations from the enterprise design and development capabilities, manufacturing capacity, after-sales service capabilities and product technical performance, quality assurance capabilities to improve the access threshold, in particular, to strengthen the safety regulatory requirements, the purpose is to effectively improve product quality and safety level. In addition, the new national standard system of new energy vehicles is gradually improving, as of now, the new energy vehicle national standard "directory" has introduced the standard 141, covers the basic electric vehicle base, vehicle, key assembly (including battery, motor, ), Electric accessories, infrastructure, interface and interface and other fields, industry standards have been in the forefront of the international.

\subsection{Attaching Great Importance to Improving the Infrastructure}

Solving the basic supporting facilities is the key to the development of new energy vehicles. Ministry of Finance, Ministry of Science and Technology, Ministry of Industry and Development, Development and Reform Commission in November 2014 issued a "new energy vehicle charging facilities on the construction of the notice" to support the new energy vehicle charging facilities construction and transformation and upgrading of rechargeable service network operation monitoring System construction. The following year in October the State Council officially released "on accelerating the electric vehicle charging infrastructure construction guidance", proposed by 2020, and basically completed a moderately ahead, with the vehicle, intelligent and efficient charging infrastructure system to meet more than 5 million electric Car charging needs. On the same day, in order to scientifically guide the construction of electric vehicle charging infrastructure, the National Development and Reform Commission, the National Energy Board, the Ministry of Industry and the Ministry of Construction and other four ministries and commissions issued a "Electric Vehicle Charging Infrastructure Development Guide (2015-2020)". In the national policy, driven by the new energy vehicle charging facilities construction results significantly. According to the information, as of June 2016, the country has built 81,000 public charging pile, an increase of $65 \%$ over the end of 2015; with more than 25,000 private charging piles, compared with the end of 2015 increased by about $12 \%$. Around the enterprises involved in charging infrastructure construction and operation of the higher enthusiasm, as of now related companies have more than 600 .

\section{Conclusion}

The development of new energy automotive industry really began at the beginning of the new century, recalled nearly 16 years of development, China's new energy automotive industry has made great progress. According to the China Association of Automobile Manufacturers data show that 2016 years ago 11 months of new energy vehicles production 427,000, sales of 402,000, an increase of $59 \%$ over the previous year and $60.4 \%$. At this rate of growth is expected, China's annual sales in 2016 will reach 450,000, has become the world's largest new energy automotive market. But behind the prosperity of the industry we should also see the whole industry still do not have the international competitiveness of the face of Europe and the United States developed a strong technical accumulation, our new energy vehicle development, in the policy and economic stimulation, but only promoted Increased production capacity, little progress in technology. Infrastructure construction is still lagging behind the industry to promote the progress of the core parts of the technical bottlenecks facing, and even worse related companies appear cheating behavior, which have to be we step by step 
through the improvement of industrial policy to solve the new energy automotive industry development And far away.

\section{References}

[1]. Wan Gang. A Summary of the Special Progress of Major Science and Technology in China's Tenth Five - year Electric Vehicle plan [J]. Chinese Science and Technology Industry, 2006(2):110-117.

[2]. Zhang Shaojie, Tian Shuo, Su Hui Shuang. Discuss On Chinese Automobile Industry's Independent Innovation Policy [J]. Business Time, 2007(5): 85.

[3]. Qian Yi, Song Kaihui, Zhang Peidong, Wang Huihui, Xu Yan. Analysis on the Policy Course of China's New Energy Automobile Industry Development [J]. Journal of Qingdao University of Science and Technology (Social Science Edition), 2016(1).

[4]. Chen Liuqin. The Development of China's New Energy Vehicle Industry and Its Policy Support [J]. Beijing car, 2010(5). 